\title{
Management Of Leg Ulcers
}

\author{
A Khachemoune, C Kauffman
}

\section{Citation}

A Khachemoune, C Kauffman. Management Of Leg Ulcers. The Internet Journal of Dermatology. 2001 Volume 1 Number 2.

DOI: $\underline{10.5580 / 1 \mathrm{~d} 85}$

\begin{abstract}
In the United States, leg ulcers present a significant clinical problem, occurring at a rate of approximately 600,000 new cases per year. (1) The most common types are venous, arterial, and neuropathic ulcers. Venous hypertension is the primary culprit in venous ulcerations. Peripheral vascular disease due to atherosclerosis with microvascular or macrovascular changes leads to ischemic ulcers. Sensory impairment with loss of protective sensation in the foot and repetitive trauma lead to neuropathic ulcers. Unusual causes of leg ulcers must be considered in the differential diagnosis. To arrive at the diagnosis, the clinician must perform a thorough history and physical examination, and order relevant investigative studies. Good management of chronic leg ulcers depends on correction of identified underlying conditions, long-term multidisciplinary care effort, and integrating traditional and new wound-healing technologies. Most patients with chronic leg ulcers benefit from the use of compression bandaging at a level appropriate to their vascular status. Venous ulcers must be managed with an arsenal of strategies to control venous insufficiency, heal the wound, and prevent recurrence. Surgery with revascularization remains the treatment of choice for chronic ischemic leg ulcers. In the absence of vascular compromise, up to 90 percent of neuropathic ulcers will heal with proper ulcer debridement, treatment of infection, saline wet-to-dry dressings, and relief of weight from the ulcerated area. The available armamentarium for wound care includes over 2000 wound dressing products and elastic compression wraps. Chronic leg ulcer treatment options have been expanded by alternatives available to treating these wounds. These alternatives include hyperbaric oxygen therapy, bioengineered skin substitutes, recombinant platelet-derived growth factors and vacuum assisted wound closure. Patients with large leg ulcers may benefit from skin grafting. Other patients may benefit from ligation and stripping of superficial veins or subfascial interruption of perforating veins.
\end{abstract}

\section{MANAGEMENT}

In the last few years there have been many new wound dressings, topical products, and skin equivalents made available. It is necessary to tailor wound care plan to the etiology of the ulcer. The use of cost-effective methods is strongly recommended for long term treatment plans. $\left({ }_{24}\right)$

\section{VENOUS ULCER MANAGEMENT}

Venous ulcers should be debrided of necrotic and fibrinous material to allow a healthy granulation tissue to develop. (Picture 6) In the absence of apparent local wound infection, antibiotics seem to have little effect in treating venous ulcers. Although povidone-iodine, acetic acid, sodium hypochlorite, and hydrogen peroxide have been shown to be toxic to cultured fibroblasts, they are helpful and remain in use. ${ }_{25}$ ) At concentrations that preserve fibroblast function these products can be used as debriding and topical antibacterial agents. ${ }_{26}$ ) Moistened saline gauzes may be appropriate for initial management of all types of leg ulcers but moisture retentive dressings are preferred. The latter help debride necrotic tissue, relieve pain and reduce the frequency of dressing change. ${ }_{27}$ ) They also are more costeffective. (24) 


\section{Figure 1}

Picture 6: Wound debridement with a curette 1

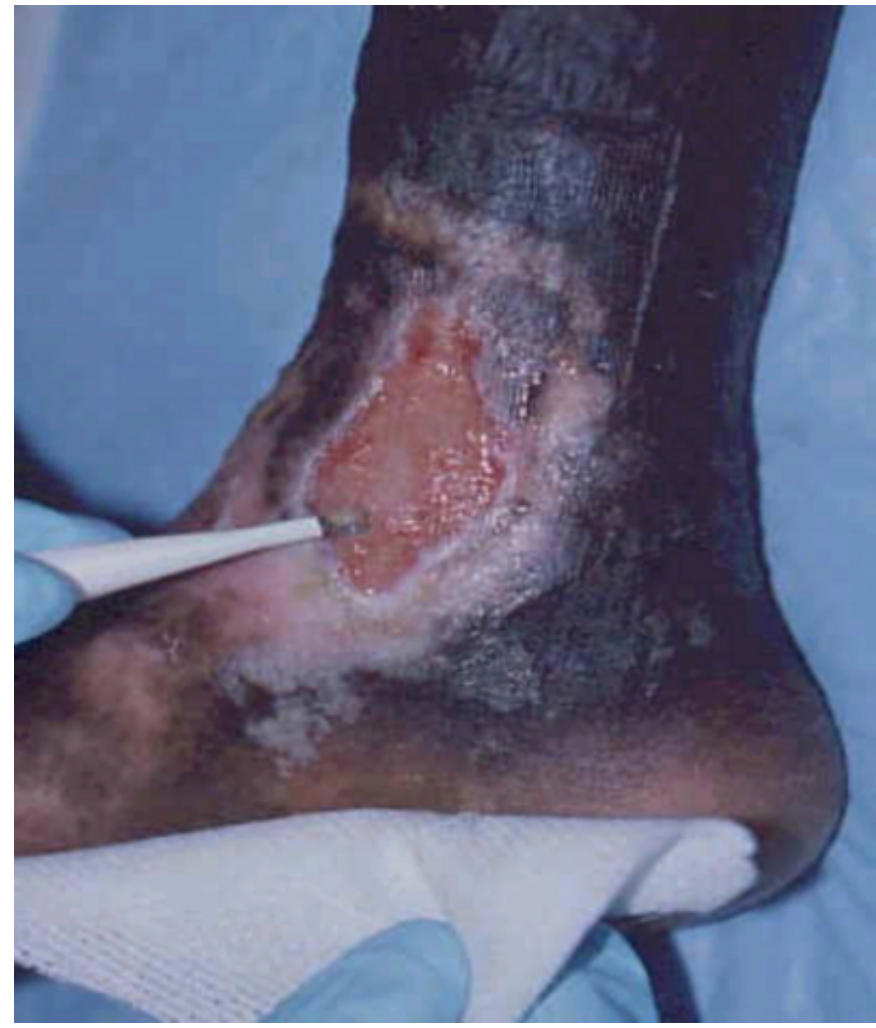

\section{Figure 2}

Picture 7: Application of a multilayer compression system

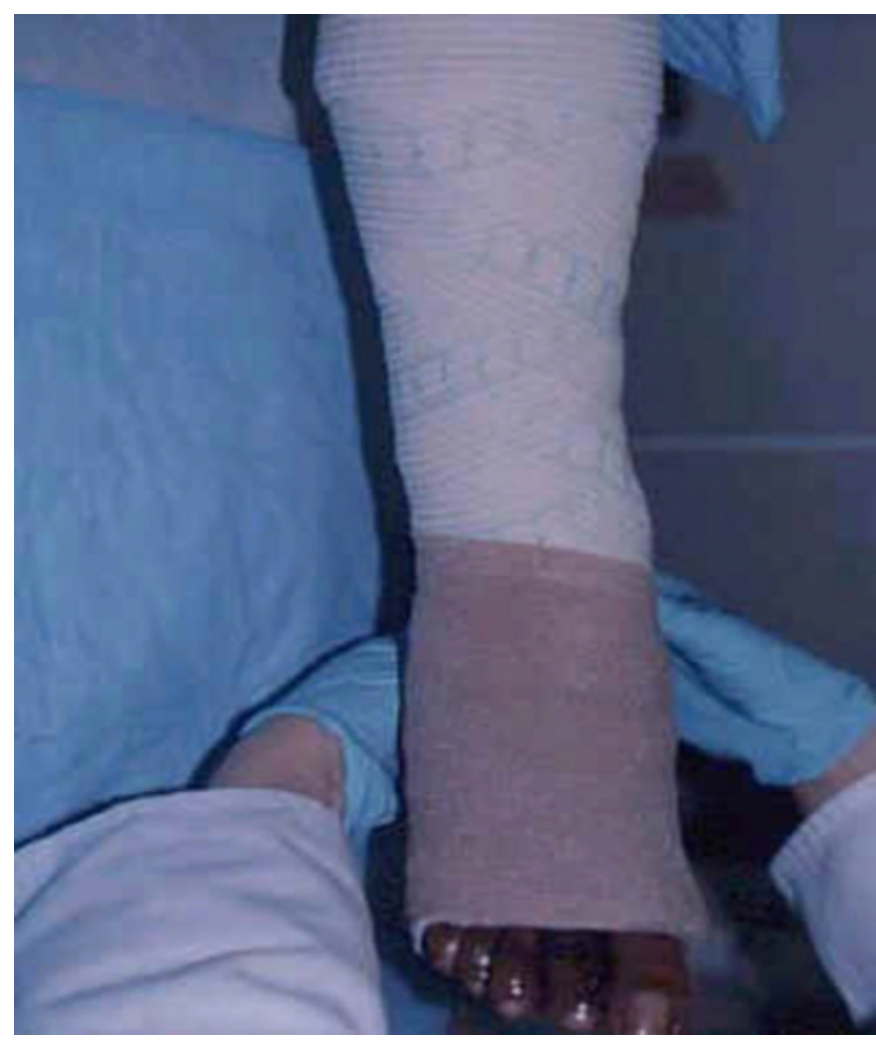

Patients with venous insufficiency are advised to elevate their legs above the heart level while sleeping, and to avoid standing for long periods. The mainstay of venous ulcer management is compression to achieve an external pressure between $30-40 \mathrm{~mm} \mathrm{Hg}$ at the ankle, this is required to prevent capillary transudate. For compression bandaging to be safely applied the ankle brachial pressure index must be at least 0.8 . $(16,25)$ The bandages should be changed once or twice a week. A summary of common compression systems is included in Table 3.

The healing rate depends on the initial size of the ulcer, but $65-70 \%$ of venous ulcers heal within six months. (16) The five-year recurrence rate of healed venous ulcers can be as high as $40 \%$. Other predictive factors for venous ulcer healing include duration of the ulcer, size, a fibrinous ulcer bed, the presence of lipodermatosclerosis, along with history of venous surgery, hip or knee replacement, and ankle brachial pressure index of less than 0.8. ${ }_{28}$ ) Surgery to correct superficial venous incompetence, as well as the ligation of incompetent perforating veins may be beneficial, curative, and may prevent recurrence. (16) At the present time, venous surgery should be reserved for patients who fail to respond to conservative treatment measures and who are adherent to medical treatment. In patients with healed ulcers who have not had surgery, the mainstay of preventing recurrence is graduated elastic compression stockings.

\section{ARTERIAL ULCER MANAGEMENT}

In daily wound care a sharp wound debridement is not recommended. Compression therapy is contraindicated in arterial disease. The mainstay of treatment of arterial leg ulcers is surgical. The aim is to restore blood supply to compromised limbs. An optimal control of associated predisposing factors, such as hyperlipidemia, hypertension, and diabetes, as well as smoking cessation and an exercise program should be included in the management plan.

\section{NEUROPATHIC ULCER MANAGEMENT}

The goal of wound dressings is to provide a warm, moist environment that is free of external contamination. Saline wet-to-dry dressings and several types of commercially available occlusive dressings (eg, hydrocolloids, alginates, foams, and films) are effective. However, none is ideal for every situation.

Various growth factors show promise. Becaplermin (Regranex), a recombinant human platelet-derived growth factor formulated into a gel, increases the incidence of and 
decreases the time needed for complete wound closure. All dressings and other wound care products are only adjuncts to careful local treatment measures, including reduction of pressure, sharp debridement of damaged tissues and control of infection. (7)

Restoration or optimization of blood supply, treatment of any active infection, and protection of the ulcerated areas should also be an integral part of the management. Offloading the foot often requires the use of a protective plaster boot with a window cut out at the site of the ulcer. After complete healing of the wound, patients should be fitted with footwear designed to minimize trauma and protect bony prominences.

Patient education about avoiding leg and foot problems is important in preventing recurrence after ulcer closure.

\section{LEG ULCER TREATMENT MODALITIES DRESSINGS}

Over 2000 types of dressings are available. See table 4 for a summary.

\section{Figure 3}

Table 4: Selected dressings and some of their properties

\begin{tabular}{|c|c|c|c|c|c|c|c|c|}
\hline \multirow[t]{2}{*}{ Drexing types } & \multirow[t]{2}{*}{ Bound same } & \multirow[t]{2}{*}{ Drexingpooperties } & \multicolumn{6}{|c|}{ Indiratione for we arcooviag to uleer charateristics } \\
\hline & & & $\begin{array}{l}\text { Mald } \\
\text { exrodate }\end{array}$ & $\begin{array}{l}\text { Modenten } \\
\text { exwalde }\end{array}$ & $\begin{array}{l}\text { Howny } \\
\text { exwoutate }\end{array}$ & $\begin{array}{l}\text { Dy } \\
\text { nectotic }\end{array}$ & $\begin{array}{l}\text { Chen } \\
\text { mourd }\end{array}$ & $\begin{array}{l}\text { Superficinal } \\
\text { grosulating }\end{array}$ \\
\hline Pillue & 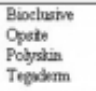 & $\begin{array}{l}\text { Adresive, thin, } \\
\text { trocperent, } \\
\text { inpemistble. }\end{array}$ & + & & & & + & \\
\hline Hydrocollowis & $\begin{array}{l}\text { Comfiel } \\
\text { Curademn } \\
\text { Dowdenn } \\
\text { Cutionen }\end{array}$ & 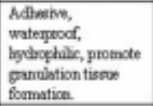 & + & + & & & & \\
\hline Foume & $\begin{array}{l}\text { Hydonsabo } \\
\text { Allonyn } \\
\text { Curfoum } \\
\text { Lydoum }\end{array}$ & 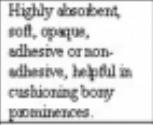 & & + & + & & & \\
\hline Hydrogeb & 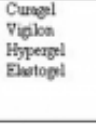 & 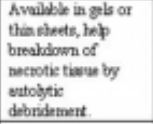 & & & & + & & \\
\hline Alginates & 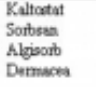 & 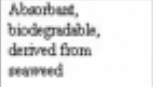 & & + & + & & & \\
\hline $\begin{array}{l}\text { Collagn } \\
\text { dissings }\end{array}$ & $\begin{array}{l}\text { Fhoweol } \\
\text { Medifl } \\
\text { Nuopl }\end{array}$ & 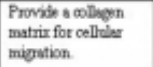 & & & & & + & \\
\hline Hydrofiers & hquesel & 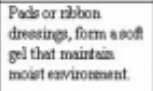 & + & + & & & & \\
\hline Hydrepolymes & Trelb & 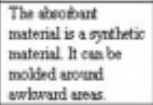 & & & & & & + \\
\hline $\begin{array}{l}\text { Super. } \\
\text { theotidents }\end{array}$ & $\begin{array}{l}\text { ComboiDetn } \\
\text { Potymen }\end{array}$ & $\begin{array}{l}\text { Highly droobant } \\
\text { maybe wed whder } \\
\text { Unua boot withs } \\
\text { weekly drosiag } \\
\text { chang. }\end{array}$ & & + & + & & & \\
\hline
\end{tabular}

\section{PENTOXIFYLLINE}

Pentoxifylline is FDA approved for the treatment of intermittent claudication. Its use in venous leg ulcers was evaluated. Pentoxifylline $800 \mathrm{mg}$ three times a day appears to be an effective adjuvant to compression bandaging for treating venous leg ulcers. $\left({ }_{29}\right)$

\section{CILOSTAZOL (PLETAL)}

Cilostazol was approved by the FDA in 1999 to treat intermittent claudication but not for the treatment of leg ulcers. It is a type 3 phosphodiesterase inhibitor. In 4 randomized placebo controlled studies enrolling 1534 patients with claudication Cilostazol $100 \mathrm{mg}$ twice daily was found to improve both pain-free and maximal treadmill walking distance. $\left.{ }_{30}\right)$

\section{HORSE-CHESTNUT SEED EXTRACT (HCSE)}

Bielanski $\left({ }_{31}\right)$ reviewed 16 randomized controlled trials using HCSE in the treatment of chronic venous insufficiency (CVI). A total of 1083 patients were included. Of these trials, 8 were placebo controlled, and 5 compared HCSE with a reference medication. None of the studies evaluated HCSE effect on venous ulcers. The studies were all short term, ranging from 2 to 12 weeks in duration. The authors concluded that HCSE may have some effect in reducing short-term symptoms of CVI, but further well-designed studies of longer duration are necessary to answer this question.

\section{HYPERBARIC OXYGEN (HBO)}

HBO was first used to assist wound healing in 1965. Many of its past uses had little or no scientific support. Hypoxic tissue, reperfusion injury, compartment syndrome, crush injury, failing flaps, burns and necrotizing infections have all been shown to respond favorably to HBO. It is used for chronic wounds, especially diabetic foot infections and leg ulcers caused by arterial insufficiency, more than for any other indication.

HBO-- 100 percent oxygen at two to three times the atmospheric pressure at sea level -- can result in arterial oxygen tension in excess of $2000 \mathrm{~mm} \mathrm{Hg}$, and oxygen tension in tissue of almost $400 \mathrm{~mm} \mathrm{Hg}$. HBO treatments at 2.0 to 2.5 atmospheres for 90 to 120 minutes are used.

There is controversy in the literature about convincing evidence of HBO's beneficial effect on healing of chronic leg ulcers. In 1999 the American Diabetes Association stated, "There are no randomized controlled trials to support the use of hyperbaric oxygen therapy to treat neuropathic diabetic foot wounds". (7) HBO is a relatively expensive treatment modality. It is considered unnecessary in simple, 
well-perfused wounds, but can be used successfully in hypoxic or ischemic wounds. London et al. (16) suggested that HBO should not be considered as treatment for lower leg ulcerations.

\section{VACUUM-ASSISTED CLOSURE (VAC)}

The FDA recently approved VAC, an innovative technique using negative pressure, for closure of chronic wounds. The technique consists in placing an open-cell foam dressing into the wound cavity and applying a controlled subatmospheric pressure (typically $125 \mathrm{~mm} \mathrm{Hg}$ below ambient pressure). This will remove chronic edema, and leads to increased localized blood flow resulting in enhanced formation of granulation tissue. Small studies with a total of 34 participants provide weak evidence suggesting that VAC may be superior to saline gauze dressings in healing chronic wounds. ${ }_{32}$ ) The VAC may be used as an adjunct treatment for chronic, nonhealing wounds, especially those that are deep and complicated.

\section{SURGERY}

Surgical treatment to correct venous hypertension or treating the ulcer itself by skin grafting is one treatment of many that could be used. Other surgical procedures include superficial stripping and excision of varices, subfascial perforating vein interruption, excision and skin grafting, excision and free flap coverage.

\section{OTHER TREATMENT OPTIONS}

There are many types of grafts and skin substitutes available; a summary of the most common types is included in Table 5.

\section{Figure 4}

Table 5: Selected grafts and skin substitutes and some of their characteristics.

\begin{tabular}{|c|c|}
\hline Type & Characteristics \\
\hline $\begin{array}{l}\text { - Autologous Split-Thickness Grafts } \\
\text { (STSG) }\end{array}$ & $\begin{array}{l}\text { Itmme diately available for use on chronic ulcers. } \\
\text { Need for donor site. }\end{array}$ \\
\hline - Cadaveric allograft & $\begin{array}{l}\text { Immediately available. } \\
\text { Risk of rejection or disease tronsmission. }\end{array}$ \\
\hline - Epidermal skin substitutes & $\begin{array}{l}\text { Fragile, no dermal subotitutes. Help relieve the } \\
\text { pain upon qplication to the ulcer. }\end{array}$ \\
\hline 1. Cultured Keretinocyte Autografts (Epicel) & Need biopsy from patient. \\
\hline 2. Cultured Keratinocyte Allografts & $\begin{array}{l}\text { Not commercially available. May be } \\
\text { cryopreserved and stored. }\end{array}$ \\
\hline - Dermal Skin substitutes & Imme diately available. \\
\hline 1. Human Cryopreserved allograft shin & Temporary coverage of the wound. \\
\hline 2. Human allograft shin tre sted (Alloderm) & Allows ultrathin split-thickness shin graft. \\
\hline 3. Bovine collagen and chondroitin sulfate & Suseeptible to infection. Requare wound \\
\hline (Integre) & excision before application. \\
\hline $\begin{array}{l}\text { - Composite (epidermal and dermal) skin } \\
\text { substitutes }\end{array}$ & \\
\hline 1. Apligraf (bilayered skin equivalent) & $\begin{array}{l}\text { Limited shelf hife ( } 5 \text { days) } \\
\text { Expensive. }\end{array}$ \\
\hline $\begin{array}{l}\text { 2. Collagen-glycosaminoglycan subotrate with } \\
\text { fibroblasts and kerdinocyte layer }\end{array}$ & $\begin{array}{l}\text { Easily handled. } \\
\text { Limited quentity. }\end{array}$ \\
\hline
\end{tabular}

\section{SKIN GRAFTS}

Pinch grafts may be performed as an outpatient procedure in patients with small ulcers. Small punch biopsies are taken from the patient's thigh and placed dermal side down on the ulcer bed. Split thickness graft is used for large ulcers. The graft may be meshed to avoid build-up of exudate underneath it. This procedure requires anesthesia and has the disadvantage of creating a new donor site ulcer.

\section{APLIGRAF (GRAFTSKIN)}

Apligraf is a bi-layered viable skin construct manufactured using neonatal foreskin keratinocytes and fibroblasts with bovine type I collagen. It was approved by the FDA for treatment of hard to heal leg venous ulcers, and for diabetic foot ulcers. $\left({ }_{33}\right)$ In a multicenter, randomized, controlled clinical trial, Apligraf has been shown to be safe and effective. It achieved more cases of complete venous ulcer closure faster than standard compression therapy alone. In a recent prospective randomized multicenter trial involving 208 patients with diabetic foot ulcers Veves et al. $\left(_{34}\right)$ concluded that application of Apligraf for a maximum of 4 weeks resulted in a higher healing rate compared to saline moistened gauzes (standard of care). Prior to Apligraf 
application to a wound, the ulcer bed preparation should be performed. This involves debridement and control of infection.

\section{OASIS}

Oasis, an FDA approved product, is used for wound management. It is a small submucosal derivate of pig intestine biomaterial, with an intact extracellular matrix; it provides a three-dimensional scaffold for remodeling to enable host cells to incorporate. It is biocompatible, acellular, has an extended shelf life, and does not require refrigeration.

\section{OTHER METHODS USED IN WOUND CLOSURE}

Cultured keratinocyte allografts could be grown in advance, cryopreserved, and stored. They provide rapid coverage of wounds. Keratinocyte allografts represent "off-the-shelf" skin replacements which avoid both the need for a patient donor site and the delay required for autologous keratinocyte culture. The chief action of keratinocyte allografts is probably cytokine-mediated. Keratinocyte allografts were used for donor sites, and partial-thickness burns. These allografts are being used as adjunct treatment for selected chronic leg ulcers, but they are not yet commercially available. $\left({ }_{35}\right)$

Other methods of wound closure include infrared UV, low energy and laser irradiation, ultrasonography, electrical stimulation, and hydrotherapy. Constant tension approximation (a technique that applies constant-tension traction to wounds), and warming therapy with heat bandages, as well as many other growth factors have been used.

\section{CONCLUSION}

Leg ulcers are very common and physicians should be familiar with the common methods used for their diagnosis and management. Some laboratory investigations may be helpful and can be ordered as part of the baseline work up. Unusual leg ulcers need more specific tests. An extensive armamentarium of wound care products is available.

Surgical repair techniques and a number of skin-substitutes are available for optimum management. A wound-healing specialist should be consulted for atypical and difficult to heal leg ulcers. More information about chronic leg ulcers can be found at: Diagnosis of Leg Ulcer, The Internet Journal of Dermatology, Volume 1 Number 2, 2002.

\section{AKNOWLEDGEMENT}

We are indebted to Dr. Tania J. Phillips for lending us the pictures

\section{References}

1. Bowman PH, Hogan DJ. Leg ulcers: a common problem with sometimes uncommon etiologies. Geriatrics. 1999 Mar;54(3):43, 47-8, 50 passim.

2. Phillips T, Stanton B, Provan A, Lew R. A study of the impact of leg ulcers on quality of life: Financial, social, and psychologic implications. J Am Acad Dermatol 1994;31:49-53.

3. Ridker, PM. Inherited risk factors for venous thromboembolism: implications for clinical practice. Clin Cornerstone. 2000;2(4):1-14.

4. Falanga V, Eaglstein WH. The "trap" hypothesis of venous ulceration. Lancet. 341(8851):1006-1008, April 17, 1993

5. Sarkar PK. Ballantyne S. Management of leg ulcers. Postgraduate Medical Journal. 76(901):674-82, 2000 Nov. 6. Boulton A. The pathogenesis of diabetic foot problems: An overview. Diab Med 1996;13(Suppl 1):812-6.

7. American Diabetes Association. Consensus Development Conference on diabetic foot wound care. Diabetes Care. 1999;22:1354-1360.

8. Goldstein DR. Vogel KM. Mureebe L. Kerstein MD. Differential diagnosis: assessment of the lower-extremity ulcer -- is it arterial, venous, neuropathic? Wounds-A Compendium of Clinical Research \& Practice, 10(4):125-31, 1998 Jul-Aug.

9. Muha J. Local wound care in diabetic foot complications: aggressive risk management and ulcer treatment to avoid amputation. Postgrad Med 1999;106(1):97-102

10. Albrant D H. Management of Foot Ulcers in Patients with Diabetes J Am Pharm Assoc 40(4):467-474, 2000. 11. Armstrong DG. Lavery LA. Vela SA. Quebedeaux TL. Fleischli JG. Choosing a practical screening instrument to identify patients at risk for diabetic foot ulceration. Archives of Internal Medicine. 158(3):289-92, 1998 Feb 9.

12. Wunderlich RP. Armstrong DG. Husain K. Lavery LA. Defining loss of protective sensation in the diabetic foot

Advances in Wound Care. 11(3):123-8, 1998 May-Jun.

13. Smieja M, Hunt DL, Edelman D, Etchells E, Cornuz J,

Simel DL. Clinical examination for the detection of protective sensation in the feet of diabetic patients.

International Cooperative Group for Clinical Examination Research. J Gen Intern Med 1999; 14:418-24.

14. Maessen-Visch MB, Hamulyak K, Tazelaar DJ, Crombag NH, Neumann HA. The prevalence of factor V Leiden mutation in patients with leg ulcers and venous insufficiency. Archives of Dermatology. 135(1):41-44, January 1999.

15. Tyrrell MR, Wolfe JHN. Critical leg ischaemia: an appraisal of clinical definitions. Br J Surg 1993; 80: 177-80. 16. London N J. Donnelly R. Ulcerated lower limb. BMJ. 320(7249):1589-1591, June 10, 2000.

17. Caputo GM, Cavanaugh PR, Ulbrecht JS, Gibbons GW, Karchmer AW. Assessment and management of foot disease in patients with diabetes. N Engl J Med. 1995;332:854-860.

18. Reiber GE. The epidemiology of diabetic foot problems. Diabic Med 1996; 13:S6-11.

19. Sibbald RG, Williamson D, Falanga V, Cherry GW. Venous leg ulcers. In Krasner DL, Rodeheaver GT, Sibbald RG (eds). Chronic Wound Care: A clinical Source Book for Healthcare Professionals, Third Edition. Wayne, PA: HMP Communications, 2001:483-494. 
20. O'Meara SM, Cullum NA, Majid M, Sheldon TA. Systematic review of antimicrobial agents used for chronic wounds. Br J Surg. 2001 Jan;88(1):4-21.

21. Eckman ME, Greenfield S, Mackey WC, et al. Foot infections in diabetic patients. Decision and costeffectiveness analyses. JAMA. 1995;273:712-20

22. Sonmezoglu K, Sonmezoglu M, Halac M, Akgun I, Turkmen C, Onsel C, Kanmaz B, Solanki K, Britton KE, Uslu I. Usefulness of (99m)Tc-Ciprofloxacin (Infecton) Scan in Diagnosis of Chronic Orthopedic Infections: Comparative Study with (99m)Tc-HMPAO Leukocyte Scintigraphy. J Nucl Med 2001 Apr;42(4):567-574 23. Mahabir RC, Taylor CD, Benny WB, Dutz JP, Snelling CF. Necrotizing Cutaneous Cryoglobulinemic Vasculopathy. Plastic \& Reconstructive Surgery. 107(5):1221-1224, April $15,2001$.

24. Khachemoune A, Phillips TJ. Cost effectiveness in wound care. In Krasner DL, Rodeheaver GT, Sibbald RG (eds). Chronic Wound Care: A clinical Source Book for Healthcare Professionals, Third Edition. Wayne, PA: HMP Communications, 2001:191-198.

25. Angle, N. Bergan, JJ. Chronic venous ulcer. BMJ. 314(7086):1019-1023, April 5, 1997.

26. McKenna PJ, Lehr GS, Leist P, Welling RE. Antiseptic effectiveness with fibroblast preservation. Ann Plast Surg. 1991 Sep;27(3):265-8.

27. Kerstein MD. Moist wound healing: the clinical perspective. Ostomy Wound Manage. 1995 Aug;41(7A
Suppl):37S-44S

28. Margolis DJ, Berlin JA, Strom B. Risk factors associated with the failure of a venous ulcer to heal. Arch Dermatol 1999;135:920-6.

29. Margolis, DJ. Pentoxifylline in the Treatment of Venous Leg Ulcers. Arch Dermatol. 136(9):1142-1143, September 2000 .

30. Hiatt WR. Medical treatment of peripheral arterial disease and claudication. NEJM. 344 (21) 1608-1621. May 24, 2001.

31. Bielanski TE, Piotrowski ZH. Horse-Chestnut Seed Extract for Chronic Venous Insufficiency. Journal of Family Practice. 48(3):171-172, March 1999.

32. Evans, D. Land, L. Topical negative pressure for treating chronic wounds. Cochrane Wounds Group. Issue 1. 2001. Date of Most Recent Update: 28-11-2000.

33. Atillasoy E. Current and investigative uses of Graftskin (Apligraf) in wound care. Wounds 2000; 12(5 Suppl A):3A 34. Veves A, Falanga V, Armstrong DG, Sabolinski ML; The Apligraf Diabetic Foot Ulcer Study. Graftskin, a human skin equivalent, is effective in the management of noninfected neuropathic diabetic foot ulcers: a prospective randomized multicenter clinical trial. Diabetes Care 2001 Feb;24(2):290-5

35. Khachemoune A, Bello YM, Phillips TJ. Factors that influence healing in chronic venous ulcers treated with Cryopreserved Human Epidermal Cultures. Dermatol Surg. (In-press). 


\section{Author Information}

Amor Khachemoune, MD, CWS

Medicine, Dermatology, Georgetown University Medical Center

Catharine Lisa Kauffman, MD

Chief, Medicine, Division of Dermatology, Georgetown University Medical Center 